\title{
The chemical compositions of Rhododendron arboreum, "Laligunras"
}

\author{
Roshani M. Shrestha*, Narendra pratapsingh Budhathoki \\ Department of Chemistry, Tri-Chandra Campus, Tribhuvan University \\ E-mail:mai_ya@live.com
}

\begin{abstract}
Rhododendron arboreum, family Ericaceae, is a medium size tree 7-14m height or shrub, Widely distributed in Nepal all along sub-tropical and temperate regions from 1200-3300m, the Rhododendron arboreum is known as 'Gunras' in Nepali. R. arboreum was declared of Nepal's national flower in 1962 by government of Nepal. The chemical compositions of the wood (stem) Of Rhododendron arboreum has been investigated on the basis of useful methods of Tappi \& ASTM. The main chemical compositions were:-Ash content (0.75\%), Extractives (4.39\%), Hollocelluloses (69.82\%), Hemicelluloses (22\%), alpha-celluloses (47.98\%), Pentosans (16.84\%), \& Lignins (24.88\%). The Lignins were analyzed by UV $\& I R$. Similarly, the fatty acid compositions of extractives were analyzed by GC/MS. The main fatty acid compositions were: Butanoic acid, Pentanoic acid, 4-Heptenoic acid, \& 8-Nonynoic acid in extractives. The solubility of wood in various solvents is a measure of extraneous components content. The solubility of different solvents were: - in cold water (7.02\%), Hot water (8.47\%), \& 1\% $\mathrm{NaOH} \mathrm{(19 \% ).} \mathrm{The} \mathrm{high}$ percentage of alpha celluloses in chemical compositions shows prospective use as a raw material for paper production along with Danphebholua (Lokta) in cottage industries of Nepal.
\end{abstract}

Keywords: Ash, Elemental composition, Rhododendron arboreum

\section{Introduction}

AS we start the twenty first century, we are concerned about issues dealing with the environment sustainability, recycling, energy, sequencing carbon, and the depletion of our natural resources by a growing world population. In many ways, we are rediscovering wood as a material. We all not however are able to realize full attention of the role that wood and wood products can play in our modern society as materials and chemical feed stock until we fully understand their chemistry and material properties. That understanding holds the keys to effective utilization ${ }^{2}$.

The investigation of chemical composition of wood is proper beneficial for paper production. Wood is a natural polymeric material that extremely variable in structure and in chemical composition as well. Even two trees of same species can have somewhat different percentage of the principal constituents in single samples of each, depending on the sources of the sampling in each tree. The chemical composition of wood varies with tree part (root, stem, or branch) type of wood (i.e. normal tension or compression) geographic location are selected for selected for the detail chemical analysis, both of them are hard wood. The chemical compositions of wood mainly contain cellulose, Hemicellulose, lignin and extractives.

Cellulose is a glucan polymer consisting of linear chians of 1,4-B-bonded anhydroglucose units. The number of sugar units in one molecular chain is referred to as the degree of Polymerization (DP). Wood

${ }^{*}$ Corresponding author 
cellulose has a DP of at least 9000 to 10,000; possibly as high as 15000 . The native cellulose is partially crystallized and is insoluble in most solvents including strong alkali.

Hemicelluloses are mixtures of polysacharides symthesized in wood almost entirely from glucose, mammose, galactose, xylose, arabimose, 4-0- methylglucouronic acid, and galactaronic acid residues. Some hardwoods contain trace amount of rhammose. Generally, hemicelluoses are of much lower molecular weight than cellulose and some are branched. They are intimately associated with cellulose and appear to contribute as a structurallcomponent in plants. Hemicelluloses are soluble in alkali and easily hydrologyed by acid.

Lignin is a complex polymer found as an extensive array of variously bonded hydroxy and secondary in the cell walls of all woody plant. It is a phenol substance consisting of an irregular array of variously bonded hydroxy and methoxy substituted phenyl propane commits.

A complete chemical analysis is account for all the components of the original wood. Thus if wood is defined as part lignin, part carbohydrate, and part extraneous materials, analysis for each of these components should sum to $100 \%{ }^{3}$.

In this article we reported the detail chemical composition of wood R. arboreum along with the fatty acid composition of extractives analyzed by GC/MS and structural analysis of macromolecules. Petterson had reviewed the chemical composition data for woods from various countries. But these dates are already decade old. There may be lots of changes in the chemical compositions due to climate changes and global warming. Reinvestigation has to start world wise. The Rhododendron species were not reported yet. The author had investigated detail chemical composition of Daphne bhoula only some chemical constituents of leaves of R. species were reported. ${ }^{4}$

Rhododendron arboreum Family Ericaceae is a medium size tree of $7-14 \mathrm{~m}$ height or a shrub widely distributed in Nepal all along subtropical cal and temperate regions from 1200-3300m. The beauty of Himalayan sight is glorified by its deep scarlet to pinkish white flower, campanulate in many flowered head on branch tips, from April to June. About 112 sps. Of the genus Rhododendron is widely distributed in the Himalayas of Nepal, Sikkim, North East India, Bhutan, China and Myanmar. The Rhododendron is 'Gurans' in Nepali. R. arboreum was declared Nepal's national flower in 1962 by the Government of Nepal, The northern part of Nepal 3000-32000m dense forest of Rhododendron arboreum is associated with birch (Betula Utelis) and Daphne bhulua (Lokta). The bark of birch has been used writing in the past Baste fibers of (Lokta) Danphe are used as raw material for handmade paper of Nepal. The wooden parts of both species can be used for paper production ${ }^{1}$. The proper industrial use of this wood is essential to know its chemical composition. The detail chemical composition of woods of R. arboreum had not yet studied. A series of compounds $\beta$-sisttosterol, friedelin, urolic acid, $\alpha-\beta$-analysis and quercetin has been isolated from leaves. The new compounds ericolin and 3-10-Epoxy glutamine has been isolated and structure has been isolated. ${ }^{1}$

\section{Methodology}

The plant R. arboreum was collected from Simak hills (2000m), Baglung, western Nepal. The plant sample of wood was taken from young tree (5-6 years old). The collected wood (stem) samples were shade dried and ground to fine particles $(40-60 \mathrm{~mm})$ dried in oven. Such oven dried sample is taken for investigation. The analysis was carried out in three phases.

1) The chemical investigation of the solid woods will be carried out by standard methods of *Tappi and ASTM*

1) Ash content (T 264 om- 88

2) Analysis of \%moisture content (T264om-88)

3) Hot water solubility (T207 om-93) 
4) $1 \% \mathrm{NaOH}$ solubility (T212 om-98)

5) Acid insoluble lignin (T222 om-98)

6) Holocelluloses (Tappi useful Method 249-75)

7) Pentosans (by bromid bromate method) ${ }^{5}$

1) Ash content (T $264 \mathrm{om}-88)$

The ash content is an approximate measure of the mineral salts and other inorganic matter in plant fiber. The ash in R. arboreum is the inorganic residue after combustion at a temperature o $575 \pm 25^{\circ} \mathrm{C}$. The ash content is calculated on the basis of the dry weight of the original sample, after the sample is ignited at a $575 \pm 25^{\circ} \mathrm{C}$.

\section{$\%$ Ash content $=(\mathrm{A} / \mathrm{B}) 100$}

$\mathrm{A}=$ weight of ash in gm

$\mathrm{B}=$ weight of test specimen in $\mathrm{gm}$

$\%$ Ash content $=0.75 \%$

\section{2) Analysis of \%moisture content (T264om-88)}

The $\%$ amount of water present in the sample is the moisture content. The moisture content based on the wet of material used which represent the amount of water in wood as a function of wet weight of wood. Weighed approximately $2.001 \mathrm{gm}$ of crude sample, transferred into crucible and dried for $2 \mathrm{hr}$ in oven at 105 degree, cooled $1 / 2$ hour in desiccator, weighed, returned crucible to oven for $1 \mathrm{hr}$. The above process is repeated after until weight constant (B).It should not change by more than $0.002 \mathrm{gm}$.

\section{Calculation}

$\%$ moisture content $=(\mathrm{A}-\mathrm{B} / \mathrm{A}) 100$

Wt. of moisture free sample $(\mathrm{B})=1.854 \mathrm{gm}$

Wt. of sample with moisture $(\mathrm{A})=2.001 \mathrm{gm}$

$=(2.001-1.854 / 2.001) 100$

$=7.35 \%$

Hence moisture content of crude sample is $7.35 \%$

\section{3) Determination of \%cold water solubility}

The solubility of wood is a measure of the extraneous components content. The Inorganic salts $\&$ molecular polysaccharides including (gums \& starch) are able to dissolve in cold water. For the determination of cold water solubility, the Rhododendron arboreum specimen extracted with cold water under reflux in a boiling water bath for 48 hours at $\left(23 \pm 3{ }^{\circ} \mathrm{c}\right)$. About $2 \mathrm{gm}$ of oven dried sample was taken in $500 \mathrm{ml}$ conical flask. It was poured $300 \mathrm{ml}$ of distilled water \& kept in $25{ }^{\circledR C}$ oven for $24 \mathrm{hrs}$. Then $3 \mathrm{hrs}$ in water bath with condenser. It was filtered with sinter glass \& washed with distilled water \& residue was kept in Oven at $105+-5$ Bc. It is kept in desiccator for $1 \mathrm{hr}$.Then weighed the sinter glass with residue. The above process was repeated until Constant weight.

\section{Calculation}

Cold water solubility $=\{(\mathrm{A}-\mathrm{B}) / \mathrm{A}\}$

Wt. of oven dried sample taken (A) $2.008 \mathrm{gm}$.

Wt. of oven dry sample after 48 hours extraction $(B)=1.867 \mathrm{gm}$.

Cold water solubility $=(2.008-1.8670 / 2.008) 100$

$=7.02 \%$ 


\section{4 ) Hot water solubility (T207 om-93)}

The hot water procedure removes a part of extraneous components such as Inorganic compounds, tannins, low molecular polysaccharides including gum, sugars \& coloring matter present in rhododendron arboreum. The hot water solubility of Rhododendron arboretum specimen is extracted with water under reflux in a boiling water bath for 3 hours.

About $2.005 \mathrm{gm}$. of oven dried sample was taken in the $500 \mathrm{ml}$ conical flask \& poured $300 \mathrm{ml}$ of distilled water. It was kept in $25{ }^{\circ} \mathrm{C}$ oven at 24 hours. Then it was also heated in water bath with condenser for 3 hours. It was filtered with sinter glass \& washed with distilled water. The residue was kept in in oven at $105{ }^{\circ} \mathrm{C}$ for 3 hours \& kept in Desiccator for 1 hour. The sinter glass with residue was weighed until the constant weight.

\section{Calculation}

$\%$ Hot water solubility $=\{(\mathrm{A}-\mathrm{B}) / \mathrm{A}\} 100$

Where, weight of oven dried sample $(\mathrm{A})=2.005 \mathrm{gm}$.

Weight of sample after extraction $(B)=1.835 \mathrm{gm}$.

$\%$ Hot water solubility $=\{(2.005-1.835) / 2.005) 100$

$=19 \%$

\section{5) $1 \% \mathrm{NaOH}$ solubility (T212 om-98)}

Hot alkali solution extracts low-molecular weight carbohydrates consisting mainly of hemicellulose and degraded cellulose in Rhododendron arboreum could indicated the degree of a fungus decay or of degradation by heat, light, oxidation etc. as the Rhododendron arboretum degrades, then the percentage of the alkali - soluble material increases.

\section{Calculation}

$\% 1 \mathrm{NaOH}$ solubility $=\{(\mathrm{A}-\mathrm{B}) / \mathrm{A}\} 100$

Where $\mathrm{A}=$ oven dried weight of test specimen before extraction $\mathrm{A}=2.005 \mathrm{gm}$.

Wt. of sample after constant weight $(\mathrm{B})=0.38095$

$\% 1 \% \mathrm{NaOH}$ solubility $=\{(2.005-0.38095) / 2.005\} 100$

$\%$ solubility in $1 \% \mathrm{NaOH}=19 \%$

\section{6) \% acid insoluble lignin units and an amorphous with three dimensional structures (Hand book)}

Lignin is a aromatic,amorphous substance containing phenolic methoxyl, and other constituents groups; it's chemical structure has not fully illucidated. Woody plant contains about 20-30\% lignins,removal of which is main objective of pulping and bleaching processes. Determiation o lignin content in R. arboreum provides information for evaluation and applicator of the processes.In this method of determination,lignin (KLason lignin) is defined as a woody specimen constituent insoluble in $72 \%$ sulphuric acid.

\section{Calculations}

$\%$ Lignin $=(\mathrm{B} / \mathrm{A}) 100$

Wt. of lignin residue $(B)=0.499 \mathrm{gm}$.

Wt. of sample after extraction $(\mathrm{A})=2.005 \mathrm{gm}$.

$\%$ Lignin $=(0.499 / 2.005) 100$

$=24.887 \%$ 
J. Nepal Chem. Soc., vol. 30, 2012

\section{6) \% Holocellulose(Tappi useful Method 249-75)}

Holocellulose contains all carbohydrate in R. arboreum, is also the sum of the cellulose and hehicellulose. The principle is baed on the specimen treated with $\mathrm{NaClO}_{2}$ and delignified,the residue is holocellulose.

\section{Calculation}

$\%$ Holocellulose $=(\mathrm{B} / \mathrm{A}) 100$

Weight of sample taken $(\mathrm{A})=2.005 \mathrm{gm}$

Weight of holocellulose $(\mathrm{B})=1.40 \mathrm{gm}$

$\%$ Hollocelluloses $=(1.40 / 2.005) 100$

$\%$ HOlocellulose $=69.82 \%$

7) \% a-cellulose (ASTM Standard D 1103)

$\alpha$-cellulose is obtained after treatment of the Hollocelulose with $17.5 \% \mathrm{NaOH}$. This procedure removes most, not all of the Hemicellulose ${ }^{9}$

\section{Calculation}

$\% \alpha$-cellulose $=(\mathrm{w} 2 / \mathrm{w} 1) 100$

Where, weight of $\alpha-$ cellulose $(\mathrm{w} 2)=0.0596$

Wt. of original oven dried sample $(\mathrm{A})=2 \mathrm{gm}$.

$\alpha-$ cellulose $=(0.9596 / 2) 100$

$=47.98 \%$

\section{8) \% Hemicellulose}

Hemicelluloses are mixtures of polysaccharides synthesized in wood almost entirely from glucose, manose, galactose, xylose, arabinose, and 4-O methylglucuroic acid and glacturonic acid residues. ${ }^{11}$

\section{Calculation}

Hemicellulose $=$ Holocellulose $-\alpha$ - cellulose

$=(69.82-47.98) \%$

$=21.82$

\subsection{8 \%Pentosans(B.L.Browning-Bromid-bromade)}

Woody fiber contains a certain amount of noncellulosic carbohydrates called Hemicellulose. Softwood Hemicellulose consists of both pentosans and hexosans. Hard wood and non- wood hemicellulose consist mainly pentosans. Pentosans content in soft woods is about 7-10\%, and hard woods and non-woods about 19- 25\%; pentosans are transformed in boiling $3.85 \mathrm{~N} \mathrm{HCl}$ to furfural, which is collected in the distillate and determined by titration. In last decades the determination of pentosans were carried out using calorimetric and spectrophotometry. Which determines only furfural (without methoxy furfural and others) soluble products present in distillate. Furfural mostly gives white colored reaction with phenol and amines in which same of color reaction is only furfural. The example, the reaction of acetic acid with furfural gives red color whereas the furfural reacted with gives blue color. This color reaction is the basic for calorimetric analysis in distillate.

About $1.5 \mathrm{gm}$. of wood sample was poured in $500 \mathrm{ml}$ of R.b flask and mixed $100 \mathrm{ml}$ of $12 \% \mathrm{HCl}$. Also some Nacl was added. After 10 minute, when $30 \mathrm{ml}$ distillate collected and added $30 \mathrm{ml}$ of $\mathrm{HCl}$ from the funnel. A distillation is carried out up to the time when $360 \mathrm{ml}$ of distillate is collected. The filtrate was diluted up to $500 \mathrm{ml}$ with $12 \% \mathrm{HCl}$. 


\section{Titratration Methods}

$100 \mathrm{ml}$ of distillate was pipet out in the $250 \mathrm{ml}$ conical flask. $25 \mathrm{ml} 0.1 \mathrm{~N}$ of bromidbromate solution was added. The conical flask was corked and kept it for 1 hour in the dark. After 1 hour added $10 \mathrm{ml} 10 \%$ solution of KI and kept again 5-10 minute in dark. It was titrated the iodine solution in the conical flask with o.1N Sodiumthiosulphate. Similarly, $100 \mathrm{ml}$ of blank solution i.e. $12 \% \mathrm{HCl}$ was taken and repeated the above same process and titrated with $0.1 \mathrm{~N}$ Thiosulphate.

\section{Calculation}

\%Furfural $=\{(b-a) * 500 * 0.0024 * 100\} / 100 \mathrm{~g}$

Where, $\mathrm{a}=$ Volume of $0.1 \mathrm{~N}$ thiosulphate for furfural

$\mathrm{b}=$ Volume of 0.1 thiosulphate for blank titration

$\mathrm{g}=$ wt. of absolute dry sample of wood in gram i.e. $1.50 \mathrm{gm}$.

\%Pentosans $=$ \%furfural $* 1.55$

Where, $1.55=$ coefficient of conversion of furfural into pentosans

Blank solution volume consume = a) $54 \mathrm{ml} \mathrm{b)} 53 \mathrm{ml}$ c) $54 \mathrm{ml}$

Distillate volume consume = a) $41 \mathrm{ml} \mathrm{b)} 42 \mathrm{ml} \mathrm{c)} 41 \mathrm{ml}$

We know, \%Furfural $=\{(\mathrm{b}-\mathrm{a}) * 500 * 0.0024 * 100\} / 100 \mathrm{~g}$

Where, $\mathrm{a}=54 \mathrm{ml}, \mathrm{b}=41 \mathrm{ml}, \mathrm{g}=1.50 \mathrm{gm}$.

\%Furfural $=\{(54-41) * 500 * 0.0024 * 100\} / 100 * 1.50$

$=(13 * 500 * 0.0024) / 1.50$

$=10.4 \%$

Pentosans $=\%$ furfural $* 1.55$

$=10.4 * 1.55$

$=16.12 \%$

$100 \mathrm{gm}$. of sample contains $4.39 \mathrm{gm}$. of extractives

$1 \mathrm{gm}$. of sample contains $4.39 / 100 \mathrm{gm}$. of extractives

$1.50 \mathrm{gm}$. of sample contains (4.39/100) 1.50

$=0.06585 \mathrm{gm}$.

So, sample without extractives $=1.50000 \mathrm{gm}-0.06585 \mathrm{gm}$

$=1.43415 \mathrm{gm}$.

$\%$ Furfural $=\{(54-41) * 500 * 0.0024\} / 1.43415$

$10.87 \%$

$\%$ Pentosans $=\%$ furfural ${ }^{*} 1.55$

$=10.87 * 1.55$

$=16.84 \%$

\section{II) Instrumental analysis}

1) Analysis of extracts:

Individual component groups by GC/MS

2) $U V / I R$

Sample Preparation of arboreum wood extract 
The plant R. arboreum was collected from simak Hills (2000m), Baglung district Nepal .The stem of tree was taken from 6-7 height. The wood of $\mathrm{R}$. arboreum $(10 \mathrm{~kg})$ were taken and dried for 2 months in shadow. It was cut into small pieces and ground $(40 \mathrm{~mm}-60 \mathrm{~mm}) .70 \mathrm{gm}$ of sample was taken in a Soxhlet $\&$ poured $300 \mathrm{ml}$ of Benzene: Ethanol (1:1) ratio. It was extracted up to 4hours

\section{GC/MS methods for the derivation of fatty acid}

Approximately, $5 \mathrm{mg}$ of fatty acid sample was dissolved in Tolune; $2 \mathrm{ml}$ of $1 \% \mathrm{H} 2 \mathrm{SO} 4$ in methanol was added \& left overnight at $50^{\circ} \mathrm{C}$ for methylation. $5 \mathrm{ml}$ of $5 \% \mathrm{NaCl}$ was added for the esterification. Then it was washed with $4 \mathrm{ml}$ of $2 \%$ KHCO3 and dried over anhydrous sodium sulphate. The extract thus obtained was used for GC/MS Injection.

\section{Analysis of extractives (Acetone and Benzene)}

Fatty acids from R. arboreum wood extracts were analyzed by GC/MS using GC/MS-Qp 2010 plus Gas chromatography spectrometer, +SHIMADZU JAPAN

\section{Results and Discussion}

The results of the Chemical analysis of basic components R. arboreum given in table- 1 for the comparison analytical data's of wood and bast (Lokta) obtained of Nepal contained from literature is also added in table ${ }^{5}$ The ash content i.e. inorganic mineral composition of R. arboreum is lower than that of Daphne bholua but it is within the range of ash content of most temperate wood .

The solubility of wood in various solvents is a measure of extraneous component content. No single solvent is able to remove all the extraneous materials. Ether is related to non-sterols and terrenes. Ethanol: Benzene (1:1) is more Polar and extracts most of the ether soluble plus most of the organic materials soluble in water. Both the extractives from ether as well as Benzene: Ethanol (1:1) is at the range of $4 \%$ which is quite higher than that of Daphne bholua wood. But the percentage of extractives extracted with Benzene: Ethanol (1:1) in R. arboreum wood is slightly lower than that of Daphne bast. It indicates the present of considerable phenolic compound and oxidized compounds in the composition of R. arboreum wood as in Daphne bast. Hot water extracts some inorganic salts of low molecular weight polysaccharides including gums and starches. Water also removes certain hemicelluloses such as arabino glacton gum present in larch wood. ${ }^{6}$ The water soluble substances are more or less double the concentration in R. arboreum wood as compared with daphne wood. But considerably three times lower than that of daphne bast fibers.

The low molecular weight carbohydrates, consisting mainly of hemicelluloses and degraded celluloses are soluble in hot alkali solution or easily hydrolyzed by acids. This low molecular weight carbohydrates is considerably cool (i.e. 90\%) in comparison to that of Daphne wood 23.7 (\%) which is very high in bast fibers of daphne bholua14.3 (\%).

Pentosans analysis measures the amount of five carbon sugars present in wood (xylose, and arabinose residues). Although the hemicelluloses consist of mixtures of both pentosans and hexoxans analysis reports xylan and arabinan content as if the five carbon sugars were present as pure pentans. The percentage of pentosans of $\mathrm{R}$. arboreum wood is between the percentages of pentosans the wood and bast samples of Daphne bholua.

Holocellulose i.e. the major carbohydrates portion of wood, is composed of celluloses and hemicellulose polymers, which is slightly lower in percentage in comparison with that of Daphne bholua wood, but within the range of holocelluloses percentage of bast fibers of daphne bholua. The percentage of $\alpha$ - celluloses in R. arboreum is higher than that of Daphne wood but comparable with that of Daphne bast. This result shows the effective use of this wood for paper production. 
The percentage of acid insoluble (Klason) in Rhododendron arboreum wood is comparatively low, while compared with that of Daphne wood higher than bast lignin. The overall comparison is $99.5(\%)$ within the range of $100(\%)$. As bast fibers (Lokta) of Daphne bholua are used as raw material for handmade paper in cottage industries of Nepal and the wood of Daphne bholua was also recommended for paper production. ${ }^{1}$ This comparative study shows the prospective use of Rhododendron wood for paper production together with Daphne bholua bast. The optimized soda and anthroquinone process (wood liquor ratio $1: 4$ at low consumption of alkali $18 \% \mathrm{Na}_{2} \mathrm{O}$ unit and temperature graph rise in temperature up to $145^{\circ} \mathrm{C}-60^{\prime}$, digestion at $145^{\circ} \mathrm{C}-60^{\prime}$, temporize up to $180^{\circ} \mathrm{C}-45^{\prime}$, digestion at $60^{\prime}$ ) can be recommended for digestion of R. arboreum wood chips separately. ${ }^{1}$

The further study required to obtain optimal regime, high yield and to characterize the pulp and paper properties. Although both the solvent Benzene: Ethanol (1:1) and Acetone extracts same compounds.

Table: 1 Chemical composition of R. arboreum (Wood)

\begin{tabular}{|c|c|c|c|c|}
\hline S.N & Components & R. arboreum wood & $\begin{array}{l}\text { Daphne bholua } \\
\text { wood }\end{array}$ & $\begin{array}{l}\text { Daphne bholua } \\
\text { bast }\end{array}$ \\
\hline 1 & Ash & 0.75 & 1.20 & $2.84 \pm 0.2$ \\
\hline 2 & Extractives: & & & \\
\hline I) & Ether & 4.795 & 1.0 & $2.2 \pm 0.2$ \\
\hline II) & Benzene: Ethanol(1:1) & 4.39 & - & \\
\hline 3 & Solubility & & & \\
\hline \multirow[t]{3}{*}{ I) } & Cold water & 7.02 & 2.7 & - \\
\hline & Hot water & 8.47 & 5.3 & $31.0 \pm 0.6$ \\
\hline & $1 \% \mathrm{NaoH}$ & 19 & - & - \\
\hline 4 & Carbohydrate & & & \\
\hline I) & Pentosans & 16.84 & 14.4 & $11.8 \pm 0.5$ \\
\hline II) & Hemicelluloses & 21.82 & 42.7 & - \\
\hline III) & $\alpha-$ celluloses & 47.98 & 34.2 & - \\
\hline IV) & Holocelluloses & 69.82 & 76.9 & - \\
\hline V) & Klason lignin & 24.887 & 31.3 & $10.3 \pm 0.6$ \\
\hline
\end{tabular}


AS given in the table-2, the GC/MS report shows the 4-Heptenoic acid is highest area percentage (42.04).Pentatonic acid and 8-Nonynoic acid are slightly equal area percentage and least area percentage of Butanoic acid in extraction.

Table-2: Fatty acid composition of R. arboreum

\begin{tabular}{|c|c|c|c|c|c|c|}
\hline S.N & Name of Compound & $\begin{array}{l}\text { Mol. } \\
\text { Formula }\end{array}$ & Area\% & $\mathrm{M} / \mathrm{Z}$ & RT & Structure \\
\hline A) & Bengene:Ethanol(1:1) & & & & & \\
\hline a) & Saturated fatty acid: & & & & & \\
\hline I) & $\begin{array}{l}\text { Methyl } \\
\text { Butanoate;Butanoic } \\
\text { acid, Methyl ester }\end{array}$ & $\mathrm{C}_{5} \mathrm{H}_{10} \mathrm{O}_{2}$ & 40.41 & 43 & 3.025 & \\
\hline II) & $\begin{array}{l}\text { Pentanoic acid, } \\
\text { Methyl ester,(E) }\end{array}$ & $\mathrm{C}_{6} \mathrm{H}_{12} \mathrm{O}_{2}$ & 24.82 & 57 & 3.283 & \\
\hline b) & $\begin{array}{l}\text { Unsaturated Fatty } \\
\text { acids: }\end{array}$ & & & & & \\
\hline I) & $\begin{array}{l}\text { 3-Heptenocacid } \\
\text { Methyl ester }\end{array}$ & $\mathrm{C}_{8} \mathrm{H}_{14} \mathrm{O}_{2}$ & 0.59 & 50 & 3.208 & \\
\hline II) & $\begin{array}{l}\text { 5-Heptenoic acid, } \\
\text { methyl ester,(E) }\end{array}$ & $\mathrm{C}_{8} \mathrm{H}_{14} \mathrm{O}_{2}$ & 29.55 & 56 & 3.617 & \\
\hline B) & Acetone Extract & & & & & \\
\hline a) & Saturated fatty acid: & & & & & \\
\hline I) & $\begin{array}{l}\text { Methyl } \\
\text { butanoate,Butanoic } \\
\text { acid, methyl ester }\end{array}$ & $\mathrm{C}_{5} \mathrm{H}_{10} \mathrm{O}_{2}$ & 2.1 & 43 & 2.533 & \\
\hline II) & $\begin{array}{l}\text { Pentanoic acid,4- } \\
\text { methyl-methyl ester }\end{array}$ & $\mathrm{C}_{6} \mathrm{H}_{11} \mathrm{O}_{2}$ & 27.21 & 57 & 2.95 & \\
\hline b) & $\begin{array}{l}\text { Unsaturated Fatty } \\
\text { acids: }\end{array}$ & & & & & \\
\hline I) & $\begin{array}{l}\text { 4-Heptenoic acid, } \\
\text { methyl ester }\end{array}$ & $\mathrm{C}_{8} \mathrm{H}_{14} \mathrm{O}_{2}$ & 42.04 & 56 & 3.142 & \\
\hline II) & $\begin{array}{l}\text { 8-Nonynoic acid, } \\
\text { methyl ester }\end{array}$ & $\mathrm{C}_{10} \mathrm{H}_{16} \mathrm{O}_{2}$ & 28.16 & 44 & 0.075 & \\
\hline
\end{tabular}

\section{Conclusion}

The detail chemical composition of R. arboreum from Nepal was reported the first time which was the analytical percentages (\%) of lignins, hemicellulose, holloceluloses, pentosans and extractives. It also concluded that the percentages (\%) sollubilities in cold water, hot water and $1 \% \mathrm{NaOH}$. Various aspects of 
analysis of R. arboreum wood extracts reveal that they contain several fatty acids. Table-2 shows that 4Heptanoic acid $>8$-Nonynoic acids> Pentatonic acid>Butanoic acid in acetone extracts and Butanoic acids $>5$-Heptenoic acids $>$ Pentatonic acids $>3$-Heptenoic acids. The high percentage of alpha celluloses in chemical compositions shows the prospective use of this wood sample as a raw material for paper production along with Danphe bhulua (Lokta) in the cottage industries of Nepal.

\section{References}

1. Shrestha R.M, complex1994 multiple use of Daphne bholua

2. Botanica orientals Journal of plant science VII 201026

3. The chemical composition of wood Pittersen the chemistry of solid wood $1984 \mathrm{p} 58$

4. Research proposal/Symposium by Dr. Roshani M. shrestha

5. The chemical composition of wood Pittersen the chemistry of solid wood $1984 \mathrm{p} 68$

6. The chemical composition of wood Pittersen the chemistry of solid wood $1984 \mathrm{p} 73$

7. Shrestha R.M etal complex use of Daphne bholua n paper production Khimiya drevensiny (wood chemistry) 1988

8. The chemical composition of wood Pittersen the chemistry of solid wood 1984 p 37

9. The chemical composition of wood Pittersen the chemistry of solid wood $1984 \mathrm{p} 71$

10. Hand books of pulping and paper making IInd Edition. Christopher J.Biermann Department of forest products and center for advanced materials research Oregon state University Corvallis' OREGON page 33

11.The chemical composition of wood Pittersen the chemistry of solid wood 1984 p62 